In his style of working, hurry had a charming leisurely quality about it, even though every minute of his time was claimed by one or the other of his selfcreated projects. Within the space of an hour he could go from cosmic-ray modulation, to rocket propellants at Thumba, to power reactors at $\mathrm{Kal}$ pakam, to the television satellite experiment, to community science education, to antenna systems for communication links, to infrared devices for surveillance of crop disease, to the administrative details of setting up a new public corporation and back perhaps to cosmic rays. And each of these transitions was deep, involving decision making, unwasteful of words, and outwardly done with a naturalness and charm which always overwhelmed his friends.

Vikram Sarabhai will be missed on the Indian scene, as a scientist, as a scientific visionary, as a doer of things and as a remarkable human being.

\section{Sir Charles Harington}

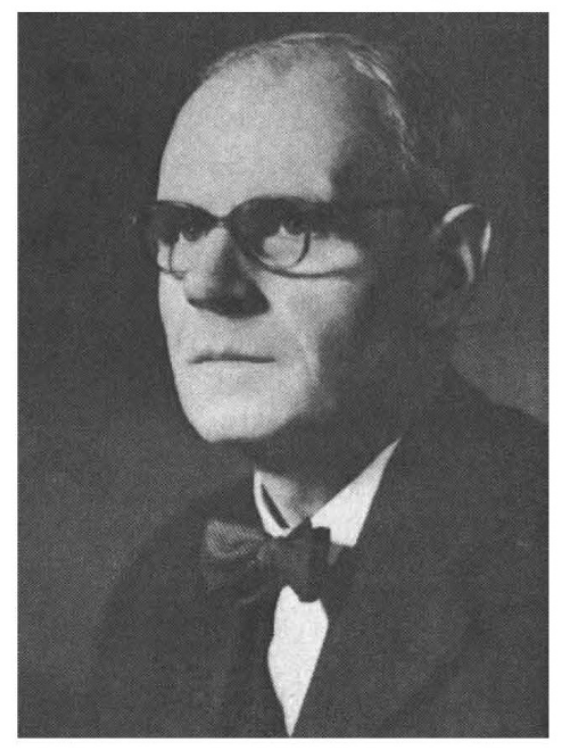

WrTH the death of Sir Charles Harington on February 4, Britain lost not only an outstanding biochemist who was one of the leading figures in the field between the two wars, but also a distinguished administrator of medical research.

Charles Robert Harington was born in 1897 in that part of Herefordshire which is close to the Welsh border. His father was a parson with strong scholarly leanings and his general family background was that of law and the army rather than of science. From Malvern College he went to Cambridge where he read chemistry. A physical disability prevented Harington from joining one of the services in the first war and he was thus able to complete his degree. From Cambridge he went to Edinburgh to work under Barger, who exerted a profound influence on his scientific development. For the rest of his life Harington became identified with biological and particularly medical research, and his knowledge of medicine and his special understanding of clinical problems dated largely from his early experience in Edinburgh. After a short stay in the United States, where he worked with H. D. Dakin and D. D. Van Slyke, he went to University College Hospital Medical School in London, where he spent twenty happy years. In 1942 he was appointed director of the National Institute for Medical Research which, at the time of his appointment, was situated at Mount Vernon, Hampstead. The staff of the institute at that time was relatively small and a large part of the work which went on was either directly or indirectly connected with the war effort. At the end of the war some new appointments to the scientific staff were made, but no great expansion was possible until, in 1949, the institute was moved to its present site in Mill Hill. Harington was mainly responsible for the considerable development of the National Institute which took place at that time.

The appointment of Harington, a non-medical man, as director of the National Institute for Medical Research was somewhat unexpected, but he fully justified the confidence which the Medical Research Council placed in him. One of his outstanding characteristics was the unfailing support and wise counsel which he gave to promising young research workers. There are many people who now occupy important positions in biomedical research in Britain who owe their success to a large extent to the help Harington gave them early in their careers. $\mathrm{He}$ also considered it important to establish close contact between the different divisions and so any attempt to overemphasize departmental boundaries was resisted. This planned cooperation between different disciplines, he considered, was one of the major differences between a national institute and the set-up of ordinary university departments. On the other hand, Harington was careful not to interfere with the scientific freedom of his staff, and this was so marked that it was sometimes difficult to obtain any advice from him on scientific matters. Harington felt that a research institute provided the opportunity for gifted people to concentrate on research and be free from major administrative responsibilities. It was for this reason that he found it difficult to delegate managerial responsibility to a significant extent, even to his senior colleagues. Harington managed to attract many outstanding workers to the National Institute and he maintained the standard of excellence which was set up in the first place, for a much smaller institute, by Sir Henry Dale.

The scientific work for which Harington will best be remembered is that which he published in 1926 and 1927 on the chemistry of thyroxine. $\mathrm{He}$ established the structure of this hormone and together with Barger described its synthesis. Two years later he succeeded in resolving thyroxine and he also characterized other iodine-containing compounds of the thyroid gland. It is perhaps difficult nowadays to appreciate fully the excitement which was caused among British biochemists when Harington first announced the structure of thyroxine at a meeting of the Biochemical Society in 1926.

In 1935 he synthesized glutathione, which at that time was an impressive achievement. A few years later Harington started a series of investigations in the field of synthetic immunochemistry, in which specific antibodies were used to examine certain metabolic processes. He was, for instance, able to suppress the action of thyroxine in rats by prior treatment with anti-thyroxyl thyroglobulin serum. This work, which involved the preparation of well-defined derivatives of proteins, was interrupted by the Second World War. Harington also worked on insulin, on the synthesis of peptides and various other topics. Techniques he used were largely those of the classical organic chemist, but his general outlook was that of a biologist. After the Second World War, Harington started experimental work again in the laboratory, but because of his heavy administrative duties he found it difficult to acquire the new techniques which were being introduced at that time. He preferred to work mainly with his own hands and never aspired to leading a large team.

Harington had a profound influence on a large number of medical scientists and biochemists, and was greatly respected in the scientific world generally. $\mathrm{He}$ was possessed of an unusually marked sense of duty and he was a man of considerable loyalty and deep affection, which he was very shy to display. He was a member of the Medical Research Council, a member of the Agricultural Research Council, an honorary secretary of the Biochemical Society and editor of the Biochemical Journal for about 12 years. Among the many honours he received was the KBE in 1962, the Royal Medal of the Royal Society in 1944 and the Gold Medal of the Society of Apothecaries in 1953. What he valued more than any honours which were bestowed on him, however, was the affection and respect which he received from almost everyone who was closely associated with him. 